\title{
Methylxanthines Accumulation in Ilex Species - Caffeine and \\ Theobromine in Erva-Mate (Ilex paraguariensis) and Other Ilex Species
}

\author{
F.H. Reginatto, M.L. Athayde, G. Gosmann*, and E.P. Schenkel \\ Faculdade de Farmácia, Universidade Federal do Rio Grande do Sul, \\ Av. Ipiranga 2752, 90610-000 Porto Alegre - RS, Brazil
}

\begin{abstract}
Ilex paraguariensis St.Hil. é uma espécie de importância econômica tendo em vista sua utilização na região meridional da América do Sul no preparo do chimarrão, uma bebida estimulante, preparada pela infusão de suas folhas e talos moídos. Este trabalho apresenta a análise de metilxantinas em folhas de I. paraguariensis e outras espécies de Ilex freqüentemente relatadas como adulterantes. A determinação do teor de metilxantinas realizada por CLAE constatou a presença de cafeína $(0,65 \%)$ e teobromina $(0,12 \%)$ em I. paraguariensis var.paraguariensis, cafeína $(0,003 \%)$ e teobromina (aprox. 0,22\%) em I. paraguariensis var. vestita, e ausência de metilxantinas em $I$. brevicuspis, I. dumosa e I. microdonta. Os resultados indicam que a acumulação de cafeína e teobromina é, até o momento, uma característica única de I. paraguariensis. Além do interesse taxonômico, esses resultados sugerem a possibilidade de identificar adulterações em erva-mate utilizando a metodologia descrita.
\end{abstract}

Ilex paraguariensis St.Hil. is an important crop used commonly at the meridional South America as a source of a stimulant beverage, called maté, prepared by infusion of its processed leaves and twigs. We describe herein the methylxanthines analyses in the leaves of I. paraguariensis and other Ilex species reported as maté adulterants. The methylxanthines content determined by HPLC were $0.65 \%$ for caffeine and $0.12 \%$ for theobromine from I. paraguariensis var. paraguariensis, and $0.003 \%$ for caffeine and $0.22 \%$ (estimated) for theobromine from I. paraguariensis var. vestita. It was not detected any methylxanthines from I. brevicuspis, I. dumosa and I. microdonta. Considering the results, simultaneous caffeine and theobromine accumulation seems hitherto to be a particular characteristic of I. paraguariensis. In addition to taxonomical significance, these data suggest that it should be possible to trace adulterations of the genuine $I$. paraguariensis using the methodology described herein.

Keywords: Ilex, methylxanthines, HPLC of methylxanthines

\section{Introduction}

Ilex paraguariensis St. Hil. is a South American native perennial tree belonging to the "holly" family (Aquifoliaceae). It has been used historically as a source of a mildly stimulant beverage, called maté ("erva-mate" or "yerbamate"), prepared by infusion of its dried leaves and twigs. Although the production of maté is becoming industrialized, its adulteration by variable quantities of leaves of other South American Ilex species is still frequent ${ }^{1,2}$. These added leaves might modify its physiological and pharmacological activities, as some of these species do not contain caffeine ${ }^{3,4}$. Despite many publications concerning the de- termination of purine alkaloids in maté leaves and commercial samples ${ }^{5-10}$, the knowledge of xanthine content of other South American Ilex species remained rather poor until recently ${ }^{4,11,12}$. Additionally, in our systematic investigation of Ilex species, we found chemical differences in the saponins structures ${ }^{13,14}$. Continuing our efforts to develop methodologies for the quality control of maté products based on its chemical composition, we describe herein the analyses of I. brevicuspis Reissek, I. dumosa Reissek, I. microdonta Reissek, I. paraguariensis St. Hil. var. paraguariensis, and I. paraguariensis St. Hil. var. vestita (Reiss.) Loes. by TLC and HPLC determination of methylxanthines in their leaves. 


\section{Experimental}

\section{Plant material}

Leaves of I. paraguariensis var. vestita were collected in August 1996 in the city of Ivaí, PR, Brazil, and mature leaves of other Ilex species were collected in February 1997 at the Botanic Garden of Porto Alegre, RS. Herbarium specimens are on deposit in the Botany Department Herbarium of Rio Grande do Sul Federal University, Porto Alegre, Brazil.

\section{Methylxanthines extract}

$15 \mathrm{~g}$ of dried ground leaves were boiled for $10 \mathrm{~min}$ in a $20 \%(\mathrm{v} / \mathrm{v})$ sulfuric acid aqueous solution $(150 \mathrm{~mL})$, then filtered. The filtrate, after being neutralized with a $25 \%$ (v/v) ammonium hydroxide aqueous solution, was extracted four times using $50 \mathrm{~mL}$ of a chloroform:isopropanol mixture $(3: 1, v / v)$. The dried organic phase was concentrated yielding the methylxanthines extract (for yields see Table 1). This residue was submitted to HPLC analyses by dilution in the mobile phase, then evaporated to dryness for TLC analyses. The final extract concentrations used for HPLC analyses were $477.6 \mu \mathrm{g} / \mathrm{mL}$ for I. brevicuspis, $569 \mu \mathrm{g} / \mathrm{mL}$ for I. dumosa, $684 \mu \mathrm{g} / \mathrm{mL}$ for I. microdonta, $51.56 \mu \mathrm{g} / \mathrm{mL}$ for I. paraguariensis var. paraguariensis, $7.93 \mu \mathrm{g} / \mathrm{mL}$ and $635 \mu \mathrm{g} / \mathrm{mL}$ for theobromine and caffeine detection, respectively, for I. paraguariensis var. vestita.

\section{$T L C$}

The methylxanthines extract was diluted in chloroform:methanol $(40: 60, \mathrm{v} / \mathrm{v})$ to obtain a solution with 250 $\mu \mathrm{g} / \mathrm{mL}$. $30 \mu \mathrm{l}$ of the extract were applied on the plates using an automatic dispenser. Chromatographic conditions were modified from literature ${ }^{15}$ as follows: Silica gel $60 \mathrm{~F}_{254}$ (Merck aluminium sheets), eluent $\mathrm{CH}_{2} \mathrm{Cl}_{2}$ :EtOH (90:5, $\mathrm{v} / \mathrm{v})$, in a saturated chamber using small dishes with $30 \%$ (v/v) aqueous $\mathrm{NH}_{4} \mathrm{OH}$, detection by quenching of the fluorescence in $\mathrm{UV}_{254}$.

HPLC

A liquid chromatograph (WATERS, model 600E) with a Rheodyne injection valve fitted with a $20 \mu \mathrm{L}$ injection loop, a variable ultraviolet detector (WATERS, model 486), and an integrator (WATERS, model 747) were used. Chromatographic separation was accomplished using column NovaPack® RPC8 (3.9 x 150 mm I.D., $5 \mu \mathrm{m})$, precolumn RPC18 (3.0 x 39 mm I.D., $50 \mu \mathrm{m})$.

An isocratic system using methanol:water $(25: 75$, v/v) as mobile phase was used at a flow rate of $0.5 \mathrm{~mL} / \mathrm{min}$ at room temperature $\left(21^{\circ} \mathrm{C}\right)$. Detection was at $280 \mathrm{~nm}$ at 0.05 AUFS. Sample solutions were injected in triplicate and their peak areas were compared with the calibration curve. Methanol was of HPLC grade (Merck).

\section{Calibration curve for HPLC}

Standard solutions of caffeine $(5.0,10.0,15.0,20.0$ and $25.0 \mu \mathrm{g} / \mathrm{mL})$ and theobromine $(1.25,2.5,5.0,7.5$ and $10.0 \mu \mathrm{g} / \mathrm{mL}$ ) were prepared using the mobile phase as solvent. The standard solutions were injected in triplicate and the peak area measured. The linearity was evaluated by linear regression and the precision and accuracy were determined by coefficient of variation (CV). Caffeine and theobromine were purchased from Merck as analytical grade.

\section{Results and Discussion}

The results of TLC analyses of methylxanthines extracts from leaves of Ilex species are shown in Table 2. Theophylline was not detected in any sample whereas caffeine and theobromine were only detected in the two I. paraguariensis varieties. It is important to remark that for I. brevicuspis and I. microdonta other substances probably related to purine alkaloids were detected and, on the contrary, I. dumosa did not present any methylxanthine in TLC.

Table 1. Yields of extracts and caffeine and theobromine contents determined by HPLC from leaves of Ilex species ${ }^{\mathrm{a}}$ :

\begin{tabular}{lccc}
\hline Ilex species & Yield of methylxanthines extract & Caffeine $(\mathrm{m} / \mathrm{m})$ & Theobromine $(\mathrm{m} / \mathrm{m})$ \\
\hline I. brevicuspis & $59.7 \mathrm{mg}$ & not detected & not detected \\
& $(0.40 \%)$ & & not detected \\
I. dumosa & $56.9 \mathrm{mg}$ & & \\
& $(0.39 \%)$ & not detected & not detected \\
I. microdonta & $85.5 \mathrm{mg}$ & & $0.12 \%$ \\
& $(0.57 \%)$ & $0.646 \%$ & $\mathrm{CV} 0.27 \%$ \\
I. paraguariensis & $257.8 \mathrm{mg}$ & $\mathrm{CV} 0.38 \%$ & $\mathrm{~b}$ \\
var. paraguariensis & $(1.72 \%)$ & $0.003 \%$ & $\mathrm{CV} 0.77 \%$ \\
I. paraguariensis & $48.0 \mathrm{mg}$ & & \\
var. vestita & $(0.32 \%)$ & & \\
\hline
\end{tabular}

a) Standard and sample solutions were injected in triplicate.

b) Theobromine was eluted with another substance, the resolution of both peaks was not adequate for quantitative determination. 
Table 2. $\mathrm{R}_{\mathrm{f}}$ values for standard methylxanthines and for detected substances by TLC in methylxanthines extracts from leaves of Ilex species:

\begin{tabular}{lc}
\hline Standard compound or sample & $\mathrm{R}_{\mathrm{f}}$ \\
\hline caffeine & 0.79 \\
theobromine & 0.29 \\
theophylline & 0.07 \\
I. brevicuspis & $0.96,0.69,0.21$ \\
I. dumosa & no methylxanthine detected \\
I. microdonta & $0.96,0.69,0.21$ \\
I. paraguariensis & $0.79,0.69,0.29$ \\
var. paraguariensis & \\
I. paraguariensis var. vestita & $0.69,0.29,0.21$ \\
\hline
\end{tabular}

Typical HPLC chromatograms of caffeine and theobromine standards, and methylxanthines extract of $I$. paraguariensis var. paraguariensis are shown in Fig. 1. The regression equations $(y=\mathrm{a} x+\mathrm{b})$ and their correlation coefficients $(r)$ were calculated as follows: $y=-45846.568$ $+425376.534 x(r=0.99997)$ for caffeine and, $y=-545.51549+210297.36 x \quad(r=0.99987)$ for theobromine. The retention time (rt) of caffeine was 8.24 min and that of theobromine was $4.03 \mathrm{~min}$. Theophylline $(\mathrm{rt}=5.30 \mathrm{~min})$ was not detected by HPLC assay, even using extracts on higher concentration. The sharp and symmetrical peaks were obtained with good baseline resolution and minimal tailing, thus facilitating accurate measurement of the peak area ratio. A HPLC mobile phase with $75 \%$ of water was idealized which is better than the usual buffered ones ${ }^{7,8,10,12}$, as it does not damage the equipment and is less expensive and easy to prepare. In this study, the HPLC procedure used had advantages of simplicity, precision, and ruggedness.

Quantitative data for methylxanthines in different Ilex samples are presented in Table 1. Caffeine and theobromine were detected only in the two I. paraguariensis varieties, and surprisingly, in opposite proportions. The methylxanthines values determined were $0.65 \%$ for caffeine and $0.12 \%$ for theobromine from mature leaves of $I$. paraguariensis var. paraguariensis. It is reported that leaves of this I. paraguariensis variety have caffeine levels varying from $0.16 \%$, in old leaves, to $1.4 \%$, in young leaves, and theobromine levels varying from $0.02 \%$, in old leaves, to $0.27 \%$, in young leaves ${ }^{9,10,16}$. In this study, the minute quantities of caffeine observed for the vestita variety, comparing to the paraguariensis variety, together with the presence of theobromine are very important, and may explain some intriguing results observed for commercial samples for which significant amounts of theobromine were reported ${ }^{8}$.

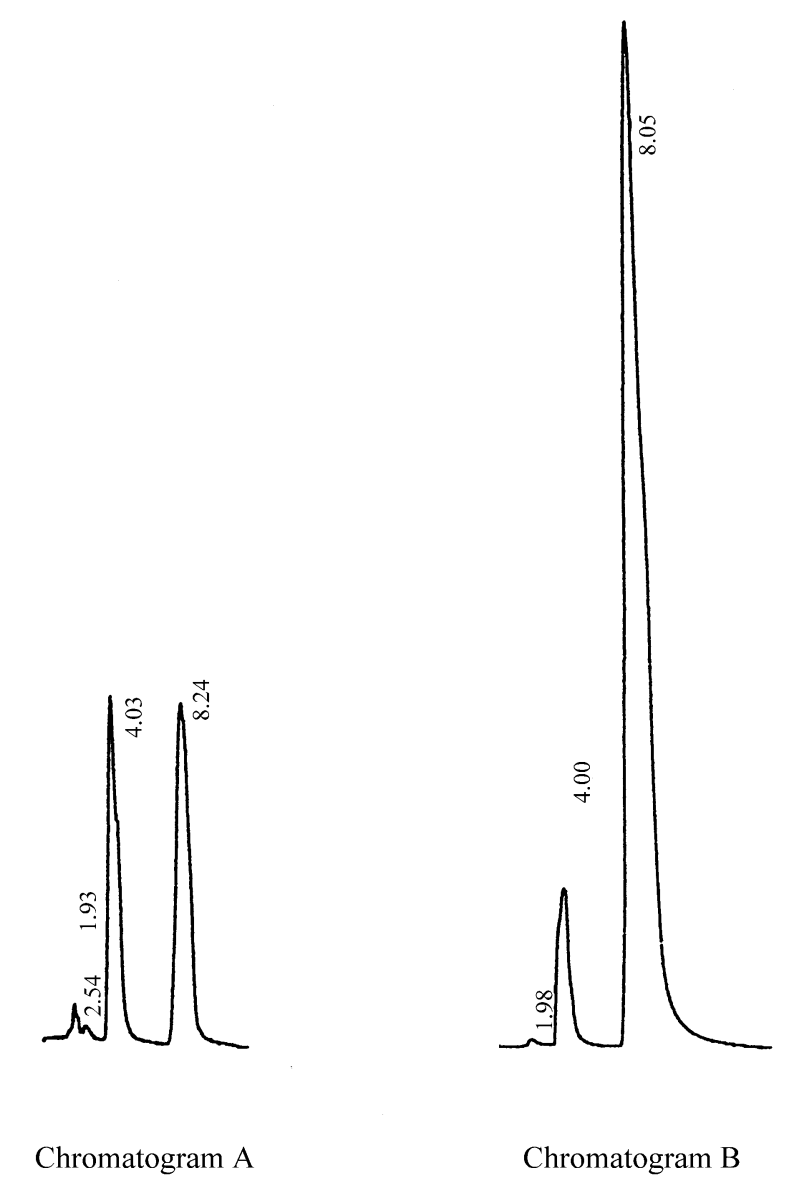

Figure 1. Chromatograms of theobromine $(\mathrm{rt}=4.03 \mathrm{~min})$ and caffeine $(\mathrm{rt}=8.24 \mathrm{~min})$ standard solutions $[\mathbf{A}]$ and methylxanthines extract from leaves of Ilex paraguariensis var. paraguariensis [B]. Chromatographic conditions: Column: WATERS Nova-Pack ${ }^{\circledR}$ RPC8 (3.9 x $150 \mathrm{~mm}$ I.D., $5 \mu \mathrm{m})$; mobile phase: methanol:water (25:75, v/v); flow rate: $0.5 \mathrm{~mL} / \mathrm{min}$; detection $280 \mathrm{~nm}$ (0.05 AUFS).

The methylxanthines values reported herein should be taken carefully as the influence of different factors on maté chemical composition is known, such as the genetic variability, the environmental conditions, harvest period, and industrial treatment of the raw material ${ }^{9,10,16,17}$. Notwithstanding this variability, the literature data cited herein allowed to indicate a minimal caffeine content for maté, presently established in Brazilian legislation as $0.5 \%$ $(\mathrm{m} / \mathrm{m})^{18}$ for commercial maté. Recent publication also showed that only in I. paraguariensis the simultaneous presence of caffeine and theobromine could be detected considering the species commonly used as maté adulterants $^{12}$. Considering this report and our results, the use of congeneric Ilex species to adulterate maté would affect significantly the methylxanthines content.

I. paraguariensis var. paraguariensis is the genuine maté, and has a large area of native dispersion, on the contrary, I. paraguariensis var. vestita, the pubescens variety, has a small area of native dispersion ${ }^{19}$. We are 
currently investigating the variability of the methylxanthines content in populations of I. paraguariensis var. vestita.

\section{Conclusions}

Considering the results obtained, simultaneous caffeine and theobromine accumulation seems hitherto to be a particular characteristic of I. paraguariensis. In addition to taxonomical significance, these data suggest that it should be possible to trace adulterations of the genuine I. paraguariensis using the methodology described herein. To our knowledge, this is the first report of methylxanthines analyses in I. paraguariensis var. vestita.

\section{Acknowledgments}

We are grateful to Afonso Olisezeski in the city of Ivaí, $\mathrm{PR}$, and Renato A. Dedecek (CNPF/Embrapa/PR) for collecting I. paraguariensis var. vestita, and to Marcos Sobral (UFRGS) for identifying all the plant material and collecting the other species. We also thanks V.S. Pires for excellent technical assistance, CAPES, CNPq, and FAPERGS for fellowships and financial support.

\section{References}

1. Edwin, G.; Reitz, P.R. In Flora Ilustrada Catarinense, Reitz, P.R., ed.; Herbário Barbosa Rodrigues/CNPq; Itajaí, 1967. Fasc. Aquifoliaceae.

2. Giberti, G.C. Dominguezia 1989, 7, 3.

3. Lendner, A. Mitt. Geb. Lebensmittelunters. Hyg 1913, 4, 42.

4. Filip, R.; Iglesias, D.I.A. de; Rondina, R.V.D.; Coussio, J.D. Acta Farm. Bonaerense 1983, $2,87$.

5. Peckolt, G. Rev. Flora Medicinal 1943, 10, 493.

6. Baltassat, F.; Darbour, N.; Ferry, S. Plant. Med. Phyt. 1984, 18, 195.

7. Vázquez, A.; Moyna, P. J. Ethnopharmacol. 1986, 18 , 267.
8. Clifford, M.N.; Ramirez-Martinez, J.R. Food Chem. 1990, 35, 13.

9. Bertoni, M.H.; Pratkricum, S.D.; Kanzig, R.G.; Cattaneo, P. An. Asoc. Quim. Argent. 1993, 81, 1.

10. Mazzafera, P. R. Bras. Fisiol. Veg. 1994, 6, 149.

11. Filip, R.; Ferraro, G.E.; Rondina, R.V.D.; Coussio, J.D. An. Asoc. Quim. Argent. 1989, 77, 293.

12. Filip, R.; Lopez, P.; Coussio, J.; Ferraro, G. Phytother. Res. 1998, 12, 129.

13. Pires, V.S.; Guillaume, D.; Gosmann, G.; Schenkel, E.P. J. Agric. Food Chem. 1997, 45, 1027.

14. Schenkel, E.P.; Gosmann, G.; Montanha, J.A.; Heizmann, B.M.; Athayde, M.L.; Taketa, A.T.C.; Pires, V.S.; Guillaume, D. Ci. Cult. 1997, 49, 359.

15. Stahl, E.; Dumont, E.; Jork, H.; Kraus, Lj.; Rozumek, K.-E.; Schorn, P.-J. Analyse chromatographique et microscopique des drogues-Manuel pratique pour les Pharmacopées Européennes; Entreprise Moderne/TechDoc; Paris, 1975.

16. Souza, P.F. de. Tecnologia de Produtos Florestais; Imprensa Nacional; Rio de Janeiro, 1947, p 206.

17. Campos, A.M. de. Desenvolvimento de extratos secos nebulizados de Ilex paraguariensis St. Hil. Aquifoliaceae (erva-mate); MSc. Dissertation; UFRGS; Porto Alegre. 149 p., 1996.

18. BRASIL. Ministério da Saúde. Secretaria de Vigilância Sanitária. Portaria no. 234, 25 de março de 1998. Diário Oficial, 29 de junho de 1998. Brasília, DF, 1998.

19. Giberti, G.C. In Erva-mate: biologia e cultura no Cone Sul, Winge, H.; Ferreira, A.G.; Mariath, J.E. de A.; Tarasconi, L.C., eds.; Ed. da Universidade/ UFRGS; Porto Alegre, p. 289, 1995. 